Journal of

Business and Strategic

Management

(JBSM)

EFFECT OF CUSTOMER RELATIONSHIP MANAGEMENT STRATEGIES ON PERFORMANCE OF MEDIUM ENTERPRISES

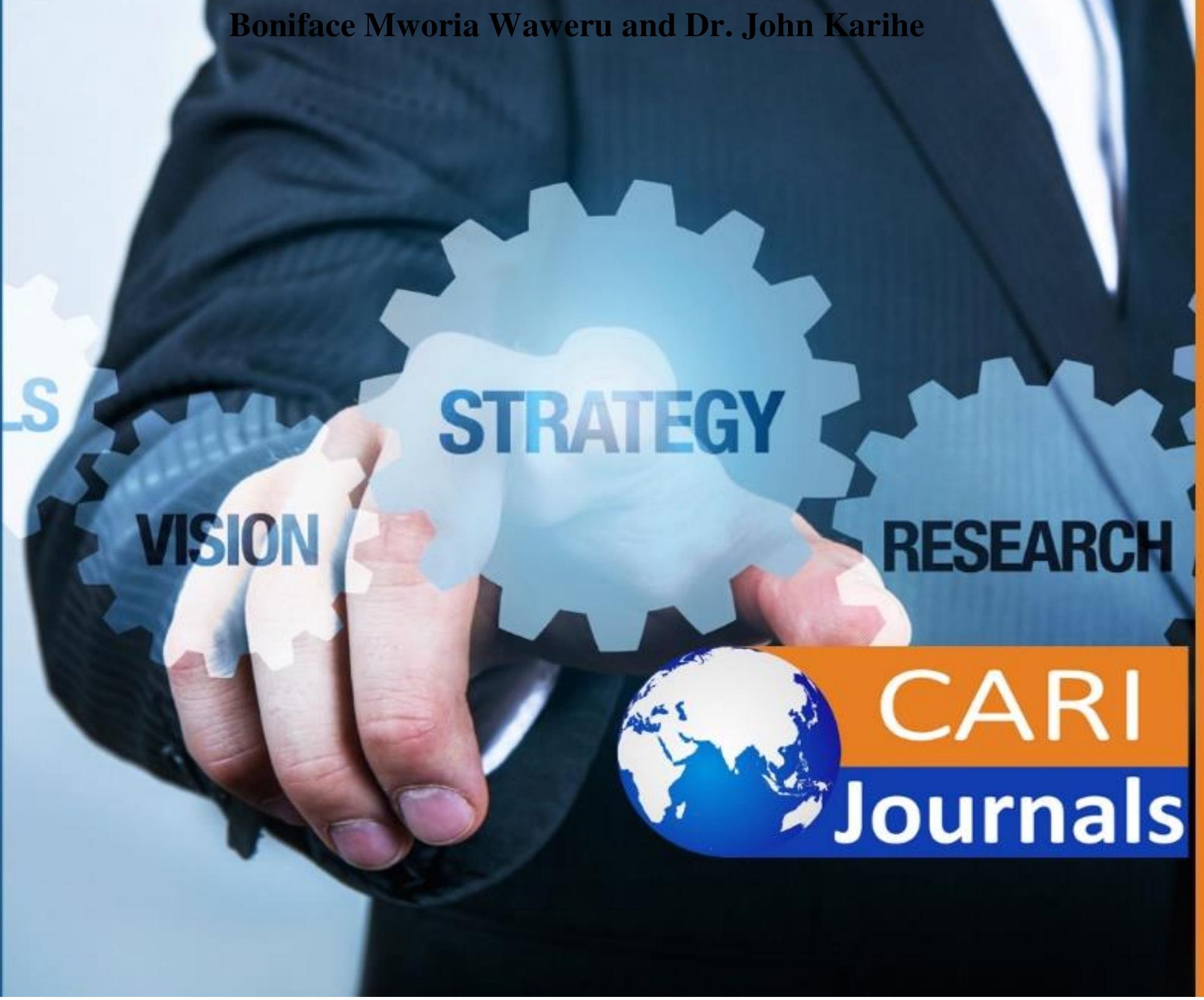




\title{
EFFECT OF CUSTOMER RELATIONSHIP MANAGEMENT STRATEGIES ON PERFORMANCE OF MEDIUM ENTERPRISES
}

\section{Boniface Mworia Waweru}

College of Human Resource and Development, Jomo Kenyatta University of Agriculture and Technology

Corresponding Author email: bonifacewaweru53@gmail.com

\section{Dr. John Karihe}

College of Human Resource and Development, Jomo Kenyatta University of Agriculture and Technology

\begin{abstract}
Purpose: The main purpose of this study was to investigate the effect of customer Relationship management strategies on performance of Medium Enterprises.

Methodology: The researcher used descriptive research design. The study site is at Kiambu County, where researcher is expected to collect data from different 5 heads of department of 40 medium enterprises. Data shall be collected using self - administered Questionnaires since the found extensive knowledge in the market hence dropped the interview. The researcher employed SPSS version 24.00 to analyze descriptive statistic. The result was presented using tables and chart.

Results: The study established that Customer Retention, Technology Infrastructure and Customer Experience positively and significantly affects performance of MSE's as shown by beta values of $0.449,0.269$ and 0.357 andsignificant values of0.000, 0.013 and 0.001 respectively. Customer Intimacy was found to positively but insignificantly affects performances of MSE's. The results implies that increasing each of the independent variable with one unit increases performance of MSE's with associated beta values. The study concludes that Customer Retention, Technology Infrastructure, Customer Experience and Customer Intimacy positively affects performances of MSE's to positive levels.
\end{abstract}

Unique contribution to theory, practice and policy: The study recommends that management of MSE's to enhance Customer Retention practices, Technology Infrastructure, Customer Experience practices and Customer Intimacy since the practices positively affects performances of the enterprises. Further research recommends in order to enhance retention firm should consider the following strategies, open communication policies, Corroborative or business partnering strategies and production innovation strategy. On second pillar(technology) the study recommends that firms should integrate technology with their good and service. On third pillar(customer experience) the study recommends that firm should support the customers throughout consumption process, implement user defined product approach and implement J.I.T system. On the last pillar study recommends that firm should be customer centric when innovate product, open communication and organize met up's. Furthermore more the study recommends further comparative study on other counties; CRM practice and their effect on performance and remaining $50.6 \%$ out of $1006 \%$ CRM strategies accounted by other indicators not included in this study.

Key Words: Customer Retention, Technology Infrastructure, Customer Experience, Customer Intimacy and Performances of MSE's. 


\section{INTRODUCTION}

The central idea in marketing during the industrial revolution period was the exchange of products between a seller and a buyer. This went on until 1850's where the production concept took shape. At the same time, firm specialized in production of a given product or service bringing about economies of scale. The product concept was the major thing in the marketing philosophy between 1900 and 1930's. During the same period, marketers realized that consumers would buy products of high quality, performance and innovative features rejecting products of low quality. This brought about requirement for continuous improvement and innovations. The selling concept was the main thing during the period between 1930s and 1950s. Firms used sales orientation with primary focus on promotion of a particular product and failing to determine new consumer desires aiming at maximizing sales volume. Later the industry established the marketing concept which dominated the period between 1940 and 1950, where firms learnt that the achievement of organization goals mostly depended on the consumer needs and wants hence effective and efficient delivery of the desired satisfaction. After achieving the heart of market the industry become more societal oriented, hence concerned with the long-run welfare of the society. Later in the year 1990's, Relationship Marketing took shape where managers emphasized Relationship between suppliers and customers. Customer Relationship Management (CRM) came about at this stage to create, maintain and enhance strong value Relationship with customers and stakeholders( Dzogbenuku\& Keelson 2019). Upon deriving development of Customer Relationship Management on the organization the researcher conducted research on the effect that customer Relationship management strategies on performance of Medium enterprise from targeted population of 40 (forty) medium enterprise..

\section{Statement of the Problem}

According to Nagwan at el., (2020) Yemeni economy largely consist of small and medium enterprise, with SMEs having $20.9 \%$ of country manufacturing industries. Consequently, in Arab countries $90 \%$ of the total firms consist of SMEs. In the same note, the majority of countries around the globe reported that SMEs provide 40-80\% of employment. SME's contribute significantly to GDP; for instant, 59\% in Palestine, 77\% in Algeria, and 25\% in Saudi Arabia. On the addition Kuwait's 90\% of private employment has emanated from SME's, in Africa Egypt SMEs comprises of $95 \%$ of the industries. Katialem at el, (2018) paper work of (Katua, 2014) instigate here at our motherland Kenya SME's are the drivers of economy due to their contribution in creation of new employment, revenue generation and driving innovations. Further (Murithii, 2017) pointed out that medium enterprises represent $99 \%$ of all enterprises in developing countries, including Kenya.

Lena et al., (2018) on her study identified that customer loyalty is dependent on the strategic implementation of CRM fundamentals, includes customer's experience, the behaviour of employees, value proposition, and Relationship development. Further she found that Customerexperience and value-proposition contributed the most hence signifying that customers count on a memorable journey. In addition they found that knowledge management should be maintained in as many SMEs as possible. In her study they found that most of SME's has embraced the means of storing customer information internally. Marolt at el.,(2018) on her study found that experience influences the intensity of social CRM, out of 6 SME's they found that they had not implemented the social CRM. Out of six only one SME has incorporated digital marketing strategy. He also found that all of the SMEs interviewed use an in - built analytical services 
offered by Social media(SM) platform such as Face book Analytical And Twitter Analysis. Marolt at el., (2018) also found that some of enterprises uses also other tools such as Google Analytical, surprisingly none of the participant enterprises found having fully implemented the SM management tool. Baashar et al.,(2020) on her study pointed out that there is significant gaps in knowledge regarding CRM in the health environment. In their study they found that CRM application, function and future are used through the internet environment. Further in their research they found that patient are positively empowered on patient's web, given that more than $70 \%$ of participants preferred to view their medical records online, make booking, payments and obtain consultations and referrals.

Kangu (2017) identified that Technologies infrastructure had a positive Relationship with customer loyalty in the hotel industry in Kenya. Further she identified that there is positive Relationship between service quality and customer loyalty in the hotel industry in Kenya .On flipside she identified that personalization of services had a positive Relationship with customer loyalty in the hotel industry in Kenya however it was statistically insignificant. Finally she found that Customer orientation had a Relationship with customer loyalty in the hotel industry in Kenya. Having underscored some of the previous researcher carried on the CRM in the past the researcher has acknowledged a gap. Hence in order meet the gap the research undertook research on effect of Customer Relationship Management strategies on performance of medium enterprises. This undertaking was triggered by research conducted by Mwaniki (2019) on Financial literacy and growth of Small and Medium Enterprises in Nyeri county who found that debt management literacy and book keeping literacy were found positive but statistically insignificant on growth of SME's.

\section{Objectives of the Study}

i. To determine the effects of Customer retention on performance of medium enterprise.

ii. To assess the effects of technology infrastructure on performance of medium enterprise

iii. To evaluate the influence of effective customer experience on performance of medium enterprises.

iv. To evaluate the effects of customer intimacy on performance of medium enterprises.

\section{LITERATURE REVIEW}

\section{Theoretical Review}

\section{Decomposed Theory of Planned Behavior (Taylor and Todd, 1995).}

Chui, N. F. (2017) reviewed the work of (Taylor and Todd, 1995) and published that decomposed theory of planned behavior is aimed to explain behavioral Intention in the information technology setting. It was launched under foundation of Theory of Planned Behaviour (TPB) that advocate that although it is universal model that aid to explain social behaviors, it have limiting factors in term of the operational components or determinant of attitudes, subjective norm and behavioral control. Although the Relationships between the belief structure and behavioral structure intention in TBT model was not well dissolved however it laid a foundation to Decomposed Theory of Planned Behavior (DTPB). Hence according to their research they found that decomposition basis of important product such as life insurance as undesirable, the need of inventing predictor became necessity (Chui, N. F, 2017). Promptly the decomposition of existing preditors of TBT may enlighten the understanding of purchasing intention towards unwanted good. Also he reframed that financial literacy has high effect with 
individual behavour on how individaul invest i.e the more financial literate customer is the higher chances of investing even in the highly risky area like life insurance. Hence he cemented that financial literacy is hypothesized to be decomposition of perceived behaviour control in the DTPB framework as unsougt product is weighed for purchase. On the same note this theory layed foundation on the research as the researcher evaluated the effect CRM strategies on performance of medium enterprise where social behaviors and their limiting factors were tasked in term of attitude, subjective norm and behavioral. These theory consigned a better perception to the researcher which open a better channel to understand client needs and wants which trigger better organization performance.

\section{The Contrast Theory}

Isaac \& Rusu (2014) reviewed the work of founding fathers of contrast theory ( Hovland, Harvey and sherif 1957) and posit that satisfaction is a function of magnitude of discrepancy expected and perceived performance. In the present Kempers \& B (2020), reviewed the work of (Yi, 1990) and discovered that when actual product didn't not meet the perceived performance ,the outcome will cause the consumer to exaggerate the inconsistency. Furthermore he revisited the work of (Cardozzo, 1965) who contributed that contrast theory points' out that receive a product less than he expected will amplify the difference between the expected and delivered. In the same accord (Oliver \& DeSarbo, 1988) discovered that this theory predict that if product perform below the expectation it will be widely be rated poorly than it is ideally. Hence the theory assumption of Contrast theory is that any outcome deviating from performance should either cause the matter to be favorably or unfavorably reaction from the disconfirmation experience that is a positive disconfirmation result to high product appraisal while negative disconfirmation will lead to poor product evaluation. According to the main objective of the study, the researcher conducted research on the effect of CRM strategies on performance of median enterprise. The theory of contrast came just in time to enlighten the researcher and the scholar on effects non performance has on operating organization. The theory of contrast dictated that any variance of perceived performance resulted on either approval or disproval hence it guided the researcher as he conducted research to arrive to a practical experience despite off not conducting experimental research.

\section{The Dissonance Theory}

According to Bran, (2020) he reviewed the work of (Leon Frestinger,1950) and reviewed that inconsistencies among the cognition that is Knowledge, opinion, beliefs about environment, oneself and our self generate uncomfortable motivation feeling(i.e. cognitive dissonance) Further Montecinos, (2020) revisited the work of (Cardozzo, 1965;Yi, 1990; Oliver, 1977) and derive that a consumer who expected high- value product and receive low-value product would identify the variance and experience a cognitive dissonance. That is disconfirmed expectation produce a state of dissonance produce pressures for its reduction, which could be achieved by adjusting the perceived disparity. The theory of Dissonance holds that "post exposure ratings are primarily a function of the expectation level because the task of recognizing disconfirmation is believed to be psychologically uncomfortable". Oliver, 1977 submitted that consumer will perceptually distort expectation-discrepant performance so as to coincide with their prior expectation level". He noted that if different occur between the perceived and product performance it will form consumer a psychological tension and try to meet the perceived thought. Cardozzo argues that psychological pricing can also affect the role of evaluating the 
products and services. He further noted that any researchers pursued this approach implicitly assume that consumers would generally find that product performance deviated in some respect from their expectations or effort expenditures and that some cognitive repositioning would be required. Theory fails as a complete explanation of consumer satisfaction, however it contributes to the understanding of the fact that expectations are not static in that they may change during a consumption experience. For instance, the importance attached to pre-holiday expectations which may change during the holiday. The theory of Dissonance derives that any negative deviation from the expectation will result to psychological tension as client try to met the expectation, for the purpose of these research these study researcher tasked the theory in order to measure the effect of performance and non performance has on the customer perception and organization performance.

\section{Conceptual Framework}

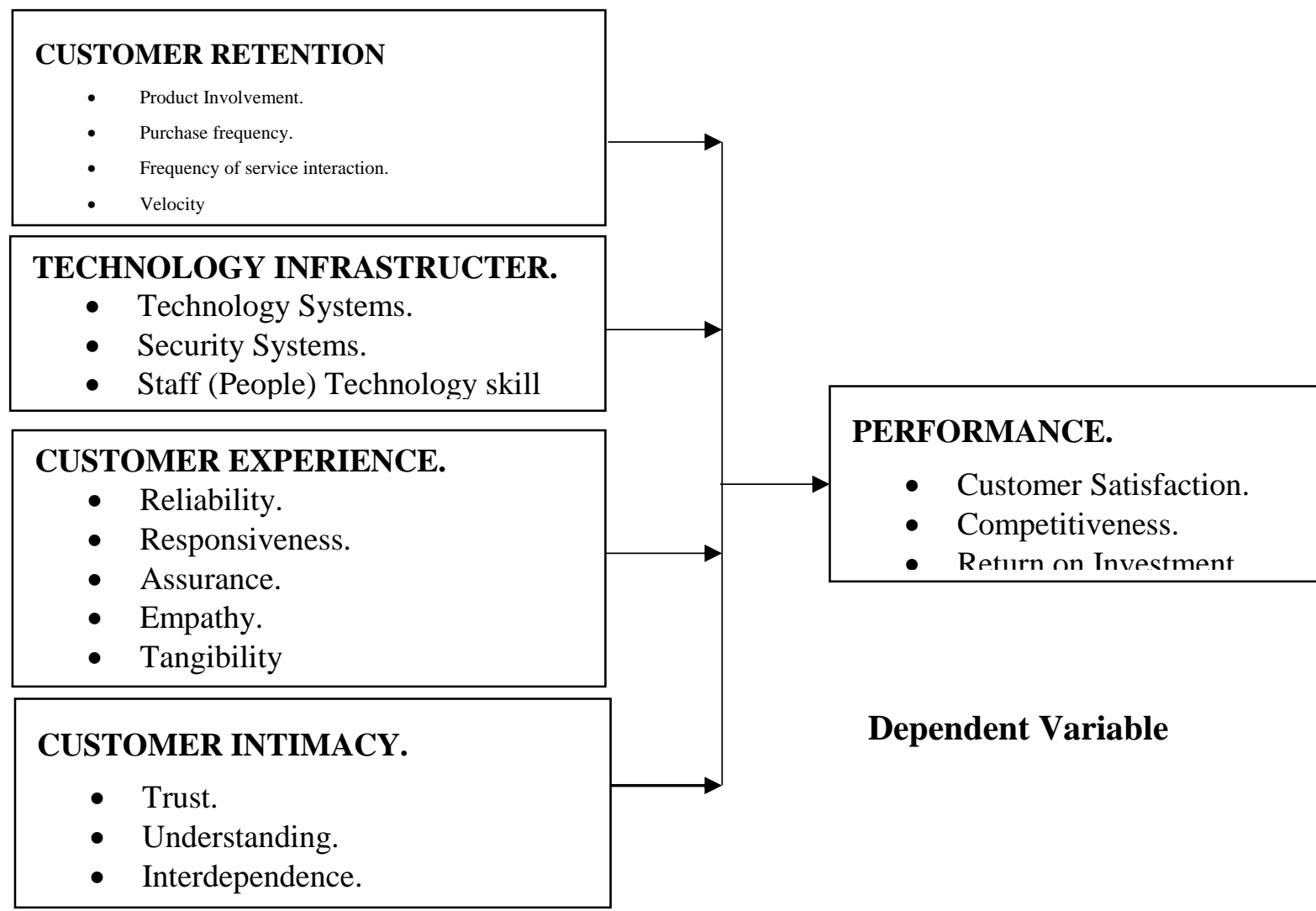

Almohaimmeed (2018) reviewed the work of (Ibojo\& Asabi, 2015) and identified that customer retention is continuity of Relationships between the organization and the consumer. In his argument he reckoned that organization are striving to retain consumer in order to deal with emergence of total quality initiative and the evolution of network economy. According to his works he detailed that many of the authors who have written on the retention have detailed that in order to achieve customer retention challenges organization should employ customer Relationship management (CRM).Further he emphasized that there are number of advantages derived by organization due to use of CRM which includes enhancement of customer loyalty, profitability and satisfaction as well as organization performance. According to his paper on pillars of Customer Retention he found that there are significant Relationships between customer 
Relationship management on customer satisfaction. Further he found that there are significant Relationships between customer satisfaction and customer profitability and between customer profitability and customer retention. On other note he found that there is no significant Relationship between customer satisfaction and retention. Finally he recommended that for any client organization to achieve consumer retention they should be able to embrace practices or programs which will attract profitability consumer. This programs includes creating loyalty programs, training programs designed to equip the internal consumer knowledge and skill which is related to creating long-term profitable consumer.

Magawati at el,.(2020) embraced that in order for a company conserve customer loyalty hence retain the existing client he must be able to provide consumer satisfaction. According to his research work he focused on factors that influence customer satisfaction and retention; some of this factor includes customer perceived value. Customer perceived value is defined as different between total customer value and the total cost incurred by customer. Other factors includes corporate image and service quality. According his work he retaliated that there is Relationship between the customer- perceived value and customer satisfaction. Nguyen et al., (2018) reinstated that companies must focus on improving service quality and company image to achieve customer satisfaction, which would in turn yield customer loyalty. Further he identified that Customer-perceived value has a significant effect on customer satisfaction. On same note he found that corporate image has a significant effect on customer satisfaction. On his third hypothesis, he found that Service quality has a significant effect on customer satisfaction. Furthermore he established that there is a significant effect on switching barriers and customer retention. Magawati at el,.(2020) retaliated that although customer satisfaction does not have effect on customer retention there is indirect Relationship that take place on consumer trust in credit process and service provider which cultivate consumer to use the company products.

\section{Technology Infrastructure.}

Marolt et al., (2018) revisited the work of (Boulding, Staelin, Ehret, \& Johnston, 2005) and found that Technology is pivot to successful CRM. Further he detailed that Technology needs to facilitate the Original marketing and customer-centric strategies. Marolt et al., (2018) further reviewed the work of (Harrigan at el 2015) and identified two area that technology can facilitate CRM, which include customer communication and customer information management. In his review he identified that the aim of every technology be it website, email and database used for CRM is to build customer insights and to instigate better products or services as well as communication to customer. Lai (2016) affirmed that Continuous technology changes set threat to reputable business model while also contributing opportunity for new services offering. Further he earmarked that advancement and dynamic growth of technology in the market relies on availability of technology, convenience, need and security. The more development derived by implementation of technology the more it triggers its development.

According to Baashar at el., (2020), on their research of HIT they identified that technology is viewed as a significant tool with; cost benefit, efficiency, quality, and safety. Other benefit associated of HIT include: improved medical services, smooth workflows, enhancing decision making support, management of proper clinical information for medical professionals, expanding the quality, safety, effectiveness of patient care, preventing medical errors, cost reduction, admissions, and paperless system. In his studies he identified that a number of studies has confirmed that success of the implementation of HIT will be dependent to survival of the 
Healthcare Industry. Further on their research they underscored that use of information technology is significant on the process of implementing CRM, in their paperwork they reviewed Yina work who remarked that effective CRM requires comprehensive data collection, integrating CRMS, IT resources such as hardware, software and infrastructure.

\section{Customer Experience.}

Noorian Imbug et al., (2018) defined customer experience a set of interaction that take place between the customer and product, which will resolute to emotion or provoke the action or reaction on consumer satisfaction. In his research work he reviewed work of other researchers and revealed that customer experience act as primary source of competitive advantage and differentiation since every experience is unique based on each brand consumed. Further he based his argument on three pillars, which includes core services, charging and brand image. On his argument he reviewed the work of (Mohammad et al, .2013) and discovered core service such as network determinant of customer experience. Further he revealed that for any company brand to remain superior in the market, organization should procure competitive pricing and distinctive network which result to positive experience to customer thought for the experience on company and brand. On his second pillar he argued that charging (costs) of service is very critical and these is the common complaint from customer concerning the perceived accuracy of bill. Further based on other authors he initiated that to ensure better customer experience, they should ensure visibility charges and regular updates on cost management. In the same spirit he remarked that fair charging price will cultivate better customer loyalty. On his last pillar that is brand image, he illuminated that brand image can be defined as a mental picture or perception of a brand, product or services which may include symbolic meaning that client are interested with specific attribute. He cemented that brand is capable to create greater customer experience into consideration that brand has capacity to create position in customer state of mind. Furthermore according to their study on the Relationship between customer experience and customer loyalty he found that there is positive influence on customer loyalty in the telecommunication industry. The study resulted that there are implication for durability of customer Relationship with service provider since it provide the best practice guideline in building customer loyalty through customer experience (Noorian Imbug et al., 2018).

Bolton et al., (2018) derived that customer experience originate from a number of interactions between customer and services providers. A number of researchers arrived that customer perception of his or her experience involved a multiple internal and subjective responses with an organization. He reviewed the work of (Lemon and verhoef, 2016) and asserted that customer experience can be conceptualized as holistic, comprised of numerous interaction across touch point involving the customer cognitive, effective, emotional, social and sensory elements. Voorhees et al,.(2017) contributed that customer experience take place throughout a number of interactions important to core services offering which includes, manifold "moment of truth" that influence customer outcome. Kranzhuhler et al, (2017) remarked that customer experience can be viewed from an organization perspective where the main agenda is designing and delivering an experience for client. Homburg et al, (2017) insinuated that management participation is the key to customer experience management through changes in cultural mindset, strategic direction and development organization capabilities. Van Doorn et al., (2017) reiterated that customer experience can be experienced from both human and non-human entities such us robots. It can be achieved through physical and virtual world which is increasingly characterize and retail setting. 


\section{Customer Intimacy.}

Nora ,(2019) reviewed (Bugel et al., 2011; Yim et al., 2008; Hansen, 2003) and derived that customer intimacy is ability to offer the best value for its products or services by regularly making adjustment to product or services in order to meet need for specific consumer. Some of key measure of client intimacy are felling of friendship of employee and comfort when client pay visit to service lender premises, having a good understanding of the process, enjoy the experience and getting pleasant experience that can freely speak for itself. Nora. L (2019) reviewed the work of (Wiersema 1993) and banked that customer intimacy can convey the product and services to clients accurately what they expected. He further instigated that consumer familiarity is a key step in the Relationship marketing cycle. In the same spirit Nora. L(2019) reviewed the work of other authors namely (Treacy and Wiersame (1996), Brock and Zhou,(2012), Lee and Know, (2011), Bugel et al (2011)) and pointed out that there are several factors that are required to be factored in order to create customer intimacy. He revealed offering unique coverage of every service, credible Relationship and customer Knowledge with strategic partners, initiating customer Relationship with sincerity and true and establishing contact and providing timely information as dependable factors to customer intimacy.

\section{RESEARCH METHODOLOGY}

The study adopted a descriptive design and 40 medium enterprises operating in Kiambu county. The unit of observation comprised of 1 Chief executive officer, 1 Operation manager, 1 Human resource Manager, 1 Marketing manager and 1 Supervisor from each of the medium enterprise. The study used structured questionnaires to collect both qualitative and quantitative data captured through a 5-point likert scale. Inferential and descriptive statistics was used to analyze data. Results of the analysis were presented by use of tables and figures. Inferential statistics was used to establish the association between independent variables and dependent variable. The study used the following regression model:

$Y=\beta_{0}+\beta_{1} X_{1}+\beta_{2} X_{2}+\beta_{3} X_{3}+\beta_{4} X_{4}+\varepsilon$

Where $\mathrm{Y}=$ Performance of Medium Enterprises, $\mathrm{X} 1=$ Customer retention, $\mathrm{X} 2=$ Technology infrastructure, $\mathrm{X} 3=$ Customer experience, $\mathrm{X} 4=$ Customer intimacy, $\beta 0=$ Regression Constant or Intercept, $\beta 1, \beta 2, \beta 3$ and $\beta 4=$ unknown coefficients of independent variables and $\varepsilon$ =error term assumed to be normally distributed with a zero variance.

\section{RESULTS}

A total of 128 questionnaires were issued to the target sample comprising of Chief executive officers, Operations Managers, Human Resource Managers, Marketing managers and Supervisors of selected Medium enterprises. 98 questionnaires were fully filled and returned. This represented a response rate of $76.6 \%$. the response rate was adequate for analysis as per Mugenda and Mugenda (2013) assertions who noted that a response rate of $70 \%$ and above is very good for analysis.

\section{Descriptive Findings and Analysis}

\section{Descriptive Statistics}

The study adopted descriptive statistics to enable the researcher provide a description of distribution of responses acquired from questionnaires distributed to the target respondents. In 
describing the responses from respondents, the study adopted means and standard deviations. The criteria involved in developing the descriptive statistics was first rating the items in the questionnaires through a scale of 1-5, then asking the respondents to rate the statements using the scale. The responses from the rated items were then averaged to get the mean response. In the questionnaire, respondents were presented with statements on each variable and were requested to rate the statements in a scale of $1-5$ where $5=$ Strongly Agree, $4=$ Agree, $3=$ Neutral,2= Disagree and $1=$ Strongly Disagree.

\section{Customer Retention}

The first objective sought to assess how customer retention affects performance of medium enterprises in Kiambu County. The descriptive results presented in table 1 shows that respondents were in agreement with statements that customer retention affect performance of our organization (mean=4.66), that high the level of customer retention result to high level of income $($ mean=4.78), that customer feel recognized when they are involved on the process of product development(mean=3.89) and that customer regularly purchase their product or services(mean=4.01). Respondents similarly agreed with the statements that customer enquire about their product and services(mean=4.45), that their organization meets with their customers frequently(mean=3.58), that their organization has put good channel of interaction(mean=3.91), that their organization regularly communicates with their client(mean=4.23) and that their organization have open channel of communication (mean=4.67). Respondents were however neutral on the fact that the management of their organization involves their client on the process of product developments(mean=3.32). On average, all respondents agreed with the statements on how customer retention affects performance as shown by average response mean of 4.15 and average standard deviation of 0.747. The results concurs with Nguyen et al., (2018) who revealed that companies must focus on improving service quality and company image to achieve customer satisfaction, which would in turn yield customer loyalty and performance.

\section{Table 1: Descriptive Statistics on Customer Retention}

\begin{tabular}{lll}
\hline Statement & Mean & $\begin{array}{c}\text { Standard } \\
\text { Deviation }\end{array}$ \\
\hline Customer retention affect performance of our organization & 4.66 & 0.311 \\
High the level of customer retention result to high level of income. & 4.78 & 0.473 \\
That management of our organization involves their client on the process of product & 3.32 & 1.291 \\
developments. & 3.89 & 0.923 \\
Customer feel recognized when they are involved on the process of product & 4.01 & 0.763 \\
development. & 4.45 & 0.782 \\
Customer regularly purchase our product or services & 3.58 & 1.002 \\
Customer enquire about our product and services & 3.91 & 0.876 \\
Our organization meets with our customers frequently & 4.23 & 0.487 \\
That our organization has put good channel of interaction & 4.67 & 0.557 \\
Our organization regularly communicates with our client & $\mathbf{4 . 1 5}$ & $\mathbf{0 . 7 4 7}$ \\
Our organization have open channel of communication. & & \\
\hline
\end{tabular}




\section{Technology Infrastructure}

The second objective sought to assess how technology infrastructure affects performance of medium enterprises in Kiambu County. The descriptive results presented in table 2 shows that respondents agreed with the statements that technology affect the daily operation of their business(mean=3.67), that technology infrastructure adds value on reporting and decision making $($ mean=3.97), that their organization has put in place the required technology infrastructure in place (mean=3.64) and that management regularly upgrade their technological infrastructure $($ mean=3.71). Additionally, respondents were in agreement with the statement that their company is connected with our consumer on real time base $($ mean $=3.81)$, that management has capacity to secure our premises using technology $($ mean=3.92), that their organization train their manpower on technological uses $($ mean=3.69), that the management regularly train our staff on technology usability (mean=3.68) and that the organization has proper tool of work on the technological field(mean=3.87). An average response mean of 3.77 and average standard deviation of 1.081 showed that all respondents were in agreement with the statements on how technology infrastructure affects performances of MSE's. The results concurs with Marolt et al., (2018) who found that Technology is pivot to successful CRM and that Technology needs to facilitate the Original marketing and customer-centric strategies.

Table 2: Descriptive Statistics on Technology Infrastructure

\begin{tabular}{lll}
\hline Statement & Mean & $\begin{array}{c}\text { Standard } \\
\text { Deviation }\end{array}$ \\
\hline Technology affect the daily operation of our business & 3.67 & 1.091 \\
Technology infrastructure adds value on reporting and decision making. & 3.97 & 0.978 \\
That our organization has put in place the required technology infrastructure in & 3.64 & 1.082 \\
place. & 3.71 & 1.012 \\
Management regularly upgrade our technological infrastructure & 3.81 & 1.064 \\
Our company is connected with our consumer on real time base & 3.92 & 0.971 \\
Management has capacity to secure our premises using technology. & 3.69 & 1.207 \\
Our organization train our manpower on technological uses & 3.68 & 1.210 \\
That management regularly train our staff on technology usability & 3.87 & 1.112 \\
That organization has proper tool of work on the technological field & $\mathbf{3 . 7 7}$ & $\mathbf{1 . 0 8 1}$ \\
Average & & \\
\hline
\end{tabular}

\section{Customer Experience}

The third objective sought to assess how customer experience affects performance of medium enterprises in Kiambu County. The descriptive results presented in table 3 shows that respondents agreed with the statements that customer experience is important tool of business(mean=4.87), that their organization contact contacts their clients after acquiring product and services to find out whether they were contented with offer(mean=3.98), that responsiveness is an important when handling customer claim or request $($ mean=4.23) and that the management provides their offer of customer request on before the end of one month(mean=3.54). Respondents similarly agreed with the statements that their organization provides the order as requested by the customer(mean=3.92), that the management keeps time when providing the offer(mean=3.77), that their staff understand the need of the market before providing an 
offer(mean=3.84), that customer can be able to access our company with ease(mean=4.17) and that their staff are equally equipped with knowledge in regard to service delivery(mean=3.71). Respondents were however neutral on the statements that their customer services desk usually receive the incoming call before the phone goes off and that customer can be able to distinguish their staff from other organization as shown by mean of 3.44 and 3.34 respectively. On average, all respondents agreed with the statement on customer experience and its effects performance of MSE's as shown by average response mean of 3.9 and average standard deviation of 0.97 . The results concurs with Noorian Imbug et al., (2018) who established that for any company brand to remain superior in the market, organization should procure competitive pricing and distinctive network which result to positive experience to customer thought for the experience on company and brand.

\section{Table 3: Descriptive Statistics on Customer Experience}

\begin{tabular}{lcc}
\hline Statement & Mean & $\begin{array}{c}\text { Standard } \\
\text { Deviation }\end{array}$ \\
\hline $\begin{array}{l}\text { Customer experience is important tool of business } \\
\text { Our organization contact contacts our client after acquiring product and services to }\end{array}$ & 3.87 & 0.103 \\
find out where they were contented with offer. & 3.98 & 1.310 \\
Responsiveness is an important when handling customer claim or request. & 4.23 & 0.214 \\
That management provides their offer of customer request on before the end of one & 3.54 & 1.264 \\
month. & 3.92 & 1.018 \\
Our organization provides the order as requested by the customer & 3.77 & 1.212 \\
The management keeps time when providing the offer. & 3.84 & 1.301 \\
Our staff understand the need of the market before providing an offer. & 1.414 \\
Our customer services desk usually receive the incoming call before the phone goes \\
off. & 3.44 & \\
Customer can be able to access our company with ease. & 4.17 & 0.619 \\
Our staff are equally equipped with knowledge in regard to service delivery. & 3.71 & 0.918 \\
& & \\
Customer can be able to distinguish our staff from other organization & 3.34 & 1.298 \\
Average & $\mathbf{3 . 9}$ & $\mathbf{0 . 9 7}$ \\
\hline
\end{tabular}

\section{Customer Intimacy}

The fourth objective sought to assess how customer intimacy affects performance of medium enterprises in Kiambu County. The descriptive results presented in table 4 shows that respondents agreed with the statements that customer intimacy influence performance of their organization(mean=4.55), that their company integrates the need of market they offer(mean=3.99), that their company shield the important organization document and information(mean=4.19) and that their company have a good channel of receiving and dispatching important document and information(mean=4.15). Respondents similarly agreed with the statements that their customer trust organizational product that they purchase and consume $($ mean=4.42), that their company depend of existences of our customer $($ mean=4.78) and that their company regularly communicate with our client on product development $(m e a n=3.82)$. Respondents were however neutral on the statements that their company evaluates all the customer suggestions and that customer highly depend on the product offered as shown by a response mean of 3.39 and 3.42 respectively. However, all respondents agreed with the 
statements on how customer intimacy affects performance of MSE's as shown by average response mean of 4.08 and average standard deviation of 0.745 . The results tallies with Nora (2019) who established that customer intimacy can only be achieved when the company have created strong bond and trusting Relationship. Thus when the trust is created the client organization is assured on repurchase.

Table 4: Descriptive Statistics on Customer Intimacy

\begin{tabular}{lll}
\hline Statement & Mean & Standard Deviation \\
\hline Customer intimacy influence performance of our organization & 4.55 & 0.191 \\
Our company integrate the need of market we offer. & 3.99 & 0.713 \\
Our company shield the important organization document and information. & 4.19 & 0.618 \\
Our company have a good channel of receiving and dispatching important & 4.15 & 0.753 \\
document and information. & 4.42 & 0.539 \\
Our customer trust organizational product that they purchase and consume. & 3.39 & 1.339 \\
Our company evaluates all the customer suggestions. & 3.42 & 1.331 \\
Customer highly depend on our product offer & 4.78 & 0.304 \\
Our company depend of existences of our customer & 3.82 & 0.915 \\
Our company regularly communicate with our client on product development. & $\mathbf{4 . 0 8}$ & $\mathbf{0 . 7 4 5}$ \\
Average & &
\end{tabular}

\section{Performance of MSE's}

The study sought to establish the performance of firms. Respondents were first requested to rate their level of agreement with statements of performance of MSE's. The results presented in table 5 shows that respondents were in agreement with statements that their clients highly recommend their products to other customers (mean=4.61), that their clients are fully satisfied with the products and services our SMEs offers(mean=4.21), that their products and services have a high competitive niche in the markets(mean=4.11), and that their firm experiences repeated purchases from customers(mean=4.23). Respondents further agreed with the statements that their firm receives purchase referrals from customers(mean=4.34) and that their company has put in place measure to reduce bureaucracy on decision process $($ mean=3.89). On average, all respondents were in agreement with the statements on performance as shown by average response mean of 4.23 and average standard deviation of 0.615. The results are in tandem with Sibanda \& Ndhlela (2018) who noted that customer Relationship management as process of creating, maintaining and enhancing strong Relationship with customers and other stakeholders with an objective to deliver long-term value to customers.

\section{Table 5: Descriptive Statistics on Performance of MSE's}

\begin{tabular}{lll}
\hline Performance of MSE's & Mean & Std.Dev \\
\hline Our clients highly recommend our products to other customers & 4.61 & 0.131 \\
Our clients are fully satisfied with the products and services our SMEs offers & 4.21 & 0.523 \\
Our products and services have a high competitive niche in the markets & 4.11 & 0.712 \\
Our firm experiences repeated purchases from customers & 4.23 & 0.711 \\
Our firm receives purchase referrals from customers & 4.34 & 0.601 \\
Our company has put in place measure to reduce bureaucracy on decision process & 3.89 & 1.013 \\
Average & $\mathbf{4 . 2 3}$ & $\mathbf{0 . 6 1 5}$ \\
\hline
\end{tabular}

The second aimed at assessing the ROI levels of the MSE's between the periods 2016 and 2020. The results presented in table 6 shows that in 2016, $18.4 \%$ of firms recorded a ROI of below kshs.500,000, 20.7\% had a ROI of between ksh 500,001 and ksh.1million, $22.4 \%$ had a ROI of 
between ksh.1million and ksh.1.5million, $14.1 \%$ had a profit of between kshs.1.5million and kshs.2million and $24.4 \%$ had a ROI of above ksh.2million. In 2017, 36.9\% of firms recorded a ROI of below kshs.500,000, 33.3\% had a ROI of between kshs.500,001 and ksh.1million, 16.7\% had a ROI of between ksh.1million and ksh.1.5million, $10.7 \%$ had a ROI of between kshs.1.5million and kshs.2million and 2.4\% had a ROI of above ksh.2million. In 2018, 24.7\% of firms recorded a ROI of below kshs.500,000, 26.3\% had a ROI of between kshs.500,001 and ksh.1million, $29.3 \%$ had a ROI of between ksh.1million and ksh.1.5million, $10.4 \%$ had a ROI of between kshs. 1.5million and kshs.2million and 9.3\% had a ROI of above ksh.2million.

In 2019, 16.7\% of firms recorded a ROI of below kshs.500,000, 19.8\% had a ROI of between ksh 500,001 and ksh.1million, $11.5 \%$ had a ROI of between ksh.1million and ksh.1.5million, $19.9 \%$ had a ROI of between kshs.1.5million and kshs.2million and $32.1 \%$ had a ROI of above ksh.2million. In 2020, 50.3\% of firms recorded a ROI of below kshs.500,000, 23.3\% had a ROI of between ksh 500,001 and ksh.1million, $11.1 \%$ had a ROI of between kshs.1million and ksh.1.5million, $10.5 \%$ had a ROI of between kshs.1.5million and kshs.2million and $4.8 \%$ had a ROI of above ksh.2million. The results shows varying performances in areas of ROI from 2016 to 2020 with both 2017 and 2020 recording the lowest levels of ROIs and 2019 the highest.

\section{Table 6: ROI of MSE's}

\begin{tabular}{llllll}
\hline Year & $\begin{array}{l}\text { Below } \\
\text { KShs500,000 }\end{array}$ & $\begin{array}{l}\text { Ksh 500,001 - ksh } \\
1 \mathrm{~m}\end{array}$ & Ksh 1m - ksh 1.5m & $\begin{array}{l}\text { Ksh 1.5m - ksh } \\
2 \mathrm{~m}\end{array}$ & Above ksh 2m \\
\hline 2016 & $18.40 \%$ & $20.70 \%$ & $22.40 \%$ & $14.10 \%$ & $24.40 \%$ \\
2017 & $36.90 \%$ & $33.30 \%$ & $16.70 \%$ & $10.70 \%$ & $2.40 \%$ \\
2018 & $24.70 \%$ & $26.30 \%$ & $29.30 \%$ & $10.40 \%$ & $9.30 \%$ \\
2019 & $16.70 \%$ & $19.80 \%$ & $11.50 \%$ & $19.90 \%$ & $32.10 \%$ \\
2020 & $50.30 \%$ & $23.30 \%$ & $11.10 \%$ & $10.50 \%$ & $4.80 \%$ \\
\hline
\end{tabular}

\section{Inferential Statistics}

\section{Correlation Results}

A correlation analysis was conducted with an aim of establishing existence of a Relationship between the independent variables (customer retention, technology infrastructure, customer experience and customer intimacy) and the dependent variable (performance of MSE's). The correlation results outlined in table 7 shows a positive and significant correlation between customer retention and performance of MSE's. This is shown by a correlation of 0.498 and a significance value of $0.000<0.05$. This implies that enhancing customer retention practices results to enhanced performances of MSE's. The results concurs with Nguyen et al., (2018) who revealed that companies must focus on improving service quality and company image to achieve customer satisfaction, which would in turn yield customer loyalty and performance. The correlation results also show a positive and significant correlation between technology infrastructure and performance of MSE's. This is shown by a correlation of 0.231 and a significance value of $0.013<0.05$. This implies that enhancing technological infrastructure results to enhanced performances of MSE's. The results concurs with Marolt et al., (2018) who found that Technology is pivot to successful CRM and that Technology needs to facilitate the Original marketing and customer-centric strategies.

The correlation results further show a positive and significant correlation between customer experience and performance of MSE's. This is shown by a correlation of 0.349 and a significance value of $0.007<0.05$. This implies that enhancing customer experience practices results to 
enhanced performances of MSE's. The results concurs with Noorian Imbug et al., (2018) who established that for any company brand to remain superior in the market, organization should procure competitive pricing and distinctive network which result to positive experience to customer thought for the experience on company and brand. The correlation results finally show a positive but insignificant correlation between customer intimacy and performance of MSE's. This is shown by a correlation of 0.108 and a significance value of $0.088>0.05$. This implies that enhancing customer intimacy practices enhances performances of MSE's to insignificant levels.

\section{Table 7: Correlation Analysis}

\begin{tabular}{|c|c|c|c|c|c|c|}
\hline & & $\begin{array}{l}\text { Customer } \\
\text { Retention }\end{array}$ & $\begin{array}{l}\text { Technology } \\
\text { Infrastructure }\end{array}$ & $\begin{array}{l}\text { Customer } \\
\text { Experience }\end{array}$ & $\begin{array}{l}\text { Customer } \\
\text { Intimacy }\end{array}$ & $\begin{array}{l}\text { Performance of } \\
\text { MSE's }\end{array}$ \\
\hline Customer Retention & $\begin{array}{l}\text { Pearson } \\
\text { Correlati } \\
\text { on } \\
\text { Sig. (2-tail }\end{array}$ & 1 & & & & \\
\hline Technology Infrastructure & $\begin{array}{l}\text { Pearson } \\
\text { Correlati } \\
\text { on } \\
\text { Sig. (2- } \\
\text { tailed) }\end{array}$ & -0.231 & 1 & & & \\
\hline Customer Experience & $\begin{array}{l}\text { Pearson } \\
\text { Correlati } \\
\text { on } \\
\text { Sig. (2- } \\
\text { tailed) }\end{array}$ & -0.213 & $-0.323^{*}$ & 1 & & \\
\hline Customer Intimacy & $\begin{array}{l}\text { Pearson } \\
\text { Correlati } \\
\text { on } \\
\text { Sig. (2- } \\
\text { tailed) }\end{array}$ & 0.024 & 0.109 & 0.078 & 1 & \\
\hline \multirow[t]{3}{*}{ Performance of MSE's } & $\begin{array}{l}\text { Pearson } \\
\text { Correlati } \\
\text { on }\end{array}$ & $.498^{*}$ & $.231 *$ & $.349^{*}$ & $.108 *$ & 1 \\
\hline & $\begin{array}{l}\text { Sig. (2- } \\
\text { tailed) }\end{array}$ & 0.000 & 0.013 & 0.007 & 0.088 & \\
\hline & $\mathrm{N}$ & 98 & 98 & 98 & 98 & 98 \\
\hline \multicolumn{7}{|c|}{ ** Correlation is significant at the 0.01 level (2-tailed). } \\
\hline \multicolumn{7}{|c|}{ * Correlation is significant at the 0.05 level (2-tailed). } \\
\hline
\end{tabular}

\section{Multiple Regression Analysis}

The purpose of conducting a multiple regression analysis is to assess the nature of Relationship between the combined independent variables and the dependent variable. A 95\% confidence interval was adopted while conducting the multiple regression analytic. The results of the analysis are presented in table 8,9 and 10. The model summary presented in table 8 shows a moderately high Relationship between independent variables and the dependent variable. This is represented by the $\mathrm{R}$ value of 0.703 . The $\mathrm{R}$ square value which represents the coefficient of determination was 0.494 implying that $49.4 \%$ of variation is the performances of MSE's was accounted by customer retention, technology infrastructure, customer experience and customer intimacy. 
Journal of Business and Strategic Management

ISSN 2520-0402 (Online)

Vol.6, Issue No. 2, pp 63-83, 2021

$\underline{\text { www.carijournals.org }}$

Table 8 Model Summary

\begin{tabular}{llll}
\hline $\mathbf{R}$ & R Square & $\begin{array}{l}\text { Adjusted } \\
\text { Square }\end{array}$ & $\begin{array}{l}\text { Rtd. Error of the } \\
\text { Estimate }\end{array}$ \\
\hline $.703^{\mathrm{a}}$ & 0.494 & 0.462 & 1.129635 \\
\hline
\end{tabular}

a. Predictors: (Constant), Customer Retention, Technology Infrastructure, Customer Experience and Customer Intimacy

Table 9 outlines the results of ANOVA. The significance of ANOVA test was to assess the statistical significance of the model used in the study linking the independent and dependent variables. The significance level of the model was assessed by comparing the value of $\mathrm{F}$ calculated with the value of F critical. The F calculated value according to the table was 13.0134 while the F critical value from the F-statistics table at $(4,93)$ and at 0.05 significance level was 2.47. The results shows that $F$ calculated value is more than $F$ critical value thus the model was considered to be statistically significance and could be used for assessing the Relationship between the independent and dependent variables.

Table 9: ANOVA (Model Significance)

\begin{tabular}{lllllll}
\hline \multicolumn{2}{l}{ Model } & \multicolumn{2}{l}{ Sum } & of & & \\
Squares & df & Mean Square F & Sig. \\
\hline 1 & Regression & 72.112 & 4 & 18.028 & 13.0134 & $0.00946^{\mathrm{b}}$ \\
& Residual & 128.836 & 93 & 1.3853 & & \\
& Total & 200.948 & 97 & & & \\
\hline
\end{tabular}

Dependent Variable: Performance of MSE's

Predictors: (Constant), Customer Retention, Technology Infrastructure, Customer Experience and Customer Intimacy

Table 10 presents the coefficients of the model adopted in the study. The results shows that customer retention positively and significantly affect the performances of MSE's in Kiambu County. This is proved by a beta value of 0.449 and sig value of $0.000<0.05$. The results bears implications that increasing customer retention practices with one units increases performances of MSE's with 0.449 units. The results tallies with Mashenene et al., (2019) findings which revealed that adoption of the right customer retention strategies enables a company experience high profitability. The results also shows that technology infrastructure positively and significantly affect the performances of MSE's in Kiambu County. This is proved by a beta value of 0.269 and sig value of $0.013<0.05$. The results bears implications that increasing technology infrastructure with one units increases performances of MSE's with 0.269 units. The results concurs with Mutuku (2018)Who established that adoption of IT contributes to enhanced organizational performance, enhances better service delivery experience, ensures transparency, effectiveness ,cost effectiveness and efficiency.

The results further shows that customer experience positively and significantly affect the performances of MSE's in Kiambu County. This is proved by a beta value of 0.357 and sig value of $0.001<0.05$. The results bears implications that increasing customer experience practices with 
Journal of Business and Strategic Management

ISSN 2520-0402 (Online)

Vol.6, Issue No. 2, pp 63-83, 2021

www.carijournals.org

one units increases performances of MSE's with 0.357 units. The results concurs with Siebert (2020) who postulated that customer experience management is increasingly concerned on developing customer experience toward the entire journey of multiple service cycles. The results finally shows that customer intimacy positively but insignificantly affect the performances of MSE's in Kiambu County. This is proved by a beta value of 0.101 and sig value of $0.096>0.05$. The results bears implications that increasing customer intimacy practices with one units increases performances of MSE's with 0.101 units. The results agree with Osei, (2017) who suggested that in order to ensure competitive edge organization should be competitive on in all three discipline namely product leadership, operational excellence and customer intimacy.

Table 10: Model Coefficients

\begin{tabular}{llllll}
\hline & \multicolumn{3}{l}{ Unstandardized Coefficients } & \multicolumn{3}{c}{ Standardized Coefficients } \\
\hline Predictors & B & Std. Error & Beta & T & Sig. \\
\hline (Constant) & 2.114 & 0.167 & & 12.659 & 0.213 \\
Customer Retention & 0.449 & 0.112 & 0.441 & 4.0091 & 0.000 \\
Technology Infrastructure & 0.269 & 0.216 & 0.258 & 1.2454 & 0.013 \\
Customer Experience & 0.357 & 0.121 & 0.349 & 2.9504 & 0.001 \\
Customer Intimacy & 0.101 & 0.098 & 0.094 & 1.0306 & 0.096 \\
\hline
\end{tabular}

The optimal regression model becomes:

\section{Performance of MSE's=2.114+ 0.449(Customer Retention) + 0.357(Customer Experience) +0.269 (Technology Infrastructure) + 0.101(Customer Intimacy)}

According to the results, customer retention bears the most significant effect on performance of MSE's, followed by customer experience, then technology infrastructure and lastly customer intimacy.

\section{Conclusion}

Customer retention has being placed like pivot towards the organization performance whose role is irreplaceable, According pareto's principle it's cheaper to maintain existing client than to procure a new one. Further he confirmed that a 5 percentage retention of existing client result to 25 percentage more increase in profitability. The respondent contributed that number of advantage associated to participant firms due to implementation of Customer retention strategy includes building customer Relationship, build trust with client, boosting revenue, increasing customer lifetime value, reduction of market rivalry, ensuring brand loyalty, getting referrals and brand ambassadors, ability to track the changes on product taste and preference, ensuring longetive Relationship with client that will yielded back their productivity and as result give birth to more revenue generation.The study published that Technology is pivot to successful CRM, benefit believed to be connected to any organization who has implemented technology. Further he noted when you improve technology it lead to improved services ,smooth workflows, enhancing decision making support, management of proper information, expanding the quality, safety, effectiveness care, preventing errors, cost reduction and paperless system. According to the research finding respondent recorded that technology facilitated easy payment or disbursement of cash to the stakeholder, easier and timely communication to customer, record 
management, improved employee productivity, real-time data processing, reducing supervision effort, improved customer services last but not least maintaining real-time daily ,costing and report writing in their daily operations.

The study illuminated that entire customer journey of consumptions has being taken care of by regularly contacting their client, this has being enhanced through paying visit to their groups setting regularly and enhancing open forum of communication that is phone communication and social media. Further the study revealed that responsiveness and assurance are important essential toward organizational performance in order to ensures that they understanding and providing consumer need timely ensuring continuous improvement, keep their client in track on changes as a key essential practice. In measure of assurance the respondent clearly stated that they have put proper action plan to ensure time keeping when attending demands, communicate regularly on product changes, being able to deliver exactly the required need, honoring agreement, offering the best product and services to void the brand disloyal, getting regular feedback from client and keeping their client alert on any changes prior to complain. Further according to the researcher any client organization who adhere to Empathy stand to achieve an increase on the level of satisfaction, help client feel the senses of ownership, provide timely solution, reduces the operations work, build longetive Relationships, improve quality of service and Accelerates innovations. Researcher published that customer intimacy is ability to offer the best value for its products or services by regularly making modification to product or services in order to meet the alarming need for specific consumer. The researcher weighed Customer Intimacy on integrity, trust ,interdependence and communication. On the measure of integrity respondent published that through enhancing integrity organization have built good reputations, built positive culture at working place, enhance respect amongst the members, build assurance with customer, enhance transparency and credibility and building sense of belonging.

\section{Recommendations of the Study}

Customer retention is an undertaking that companies and organization acquires to reduce the number of client defection to other providers hence researcher seeks to recommend as follows. That medium enterprise should implement Bottom- up-Approach strategy, this approach being to identify consumer need and provide the need rather that providing un-quantified need. That management of participant firm should implement participatory strategy, this approach seek to allow client to participate on their new product and services production. This can be achieved by opening communication forum, here client should be able to input their need of product, face by face participatory and sheaving information from their client complains record. The researcher reviewed that Science, technology and development played a key role on progression of Millennium Development Goal and new ambitious Agenda 2030. Therefore researcher recommends that management of participating firms should integrate their needs and technology in order to move together with the market needs. Further, that management should involve their internal and the external client on the process of new technology development in order to give their inputs. That, for company to remain competitive interim technological development and to achieve the objective they should launch a reward based competition for the best innovators which will champions them to be more productive and competitive. Furthermore, that management should regularly train their external and internal client on technology usability in order to be user friendly and hence achieve their desire objectives.

The literature review banked that customer experience is a set of interaction that take place between the customer and product which result to provoke emotion, action or reaction on 
consumer satisfaction. On that note researcher recommends to the management of participating medium enterprises that in order to build durable customer experience, client organization should support their client throughout consumption process. Consumer support should either be achieved by opening up communication channel either to complain, ask question on regard to expectation or either providers user manual that elaborates the service and product offered, in case they are dealing on product they should be open to demonstrate the usability and lastly that they should warranty their products where applicable. The researcher recommends that in order remain competitive, Medium enterprises should develop a durable product that will be attached with the need of client since they understand them better, their pain, need and desire even before they have identified them. Further the researcher advocate that since the reason any business been in the market is to provide the need, they should own client need and Innovate product according to the market desire. Furthermore the researcher recommended that Management should ensure that they have open conversations with their client, this will aid to listen, involve client, consume together and identity their need in order to have better understanding on their client.

\section{ACKNOWLEDGEMENT}

I wish to take this opportunity to acknowledge the Late DR. Isaac Mirenga for helpful discussion and supervision which championed my proposal. Further, other appreciation goes to my current supervisor DR. John Karihe who stepped in to bridge the gap after demise of my supervisor Late DR. Isaac Mirenga until the tail end. My sincere gratitude goes to the Chief executive officers, Operations Managers, Human Resource Managers, Marketing managers and Supervisors and Management of 40 (forty) medium enterprise and my research assistant who willingly supported me throughout my data collection process. Last but not the least, I wish to appreciate my entire family for their motivation and any other unlisted person who championed my thesis.

\section{REFERENCES}

Abou-Shouk, M. S. (2019). The effect of customer Relationship management practices on airline customer loyalty. Journal of Tourism, Heritage \& Services Marketing , 11-19.

Almohaimmeed, B. (2018). Pillars of Customer retention:An empirical study on the influence of Customer satisfaction,Customer loyalty,Customer Profitability on Customer retention. Serbian Journal of Management .

Anton Siebert, A. G. (2020). Customer Experience Journeys:Loyalty Loop Versus Involvement Spirals. Journal of Marketing. , 45-66.

Arshad, A. B. (2018). Customer Relationship Management Model From Strategic Approach:A knowledge Management Perspective. International Journal Of Research Science \& Management, 124-135.

Ayuna, I. (2018). Impact of Emerging Technology on international Trade;Case of Three dimensional (3D) prininting and customs Authority In East AFfrica Comminity. University of Nairobi.

Battista, E. P. (2020). Impact of emerging technologies on work; a review of evidence and application of human resource function. Emerald Open Research . 
Journal of Business and Strategic Management

ISSN 2520-0402 (Online)

Vol.6, Issue No. 2, pp 63-83, 2021

www.carijournals.org

Chui, N. F. (2017). Decomposing the Theory Of Planned Behaviour and Incorporating Spritual Intellingence to Further Understand Purchase Intention of Life Insuarance and Takaful. International Journal of Economic Research. , 244.

Connor K.Warner, C. V. (2018). Defining technology Technology For Learning:Cognative and Physical Tool of Inquiry. Technology for learning in middle Grades .

Dr.Fredrick M.Kalui, B. K. (2018). Research jounal of Finance and Accounting. Influence of selected factors on choice of capital structure of small and medium Entreprises (SME"S) IN Kiambu county, kenya, vol 9.No.10,2018.

Fatuma Ali Rajab, D. P. ( 2021). Influence of Customer Relationship management on performance of Manufacturing Firms In Kenya. International Journal of supply chain Management, 14-28.

Harcourt Horsfall \& Adiele, K. C. (2020). Customer Intimacy Adoption and Customer Retention: A Study of Bakery Firm in Rivers State Of Negeria. International Journal of Social Sciences and Management Research .

Havir, D. (2017). A comparision of the Approach to Customer Experience Analysis. Economics and Business.

Isaac Ruto Katealem, D. M. (2018). Enterpreneurial Orientation And Small And Medium Enterprise Growt:Emprical Evidence From SME's in manafucturing sector of Nairobi county,Kenya. Intenational Journal Of Enterpreneurship and Project mangaement , 3853.

Jairus, M. N. (2018). Customer Relationship Management straregies and retention. Nairobi.

Jairus, M. N. (2018). Customer Relationship Management Strategies and Retention amoung commericial Bank in Nakuru Town kenya.

Kangu, M. A. (2017). The role of customer Relationship Management Dimension on Customer Loyalty In The Hotel Industry in Kenya.

Kempers, J. B. (May 2020). Effects of new technologies on customer satisfaction. Jonkoping University.

Magawati Simanjuntak, N. E. (2020). Enhancing customer retention using customer Relationship management approach in car loan Bussiness. Marketing Research Article.

Makasi, A. (2014). The Impact of Operational Customer Relationship Management on Customer Loyalty. Mediterranean Journal of Social Sciences , 23.

Manoj Kumbhar, P. B. (2017). Paper on Customer Care Unit For Shopping Mall. International Research Journal of Engineering and Technology (IRJET) .

Marjeta Marolt, H.-D. Z. (2018, october). Exporatory study of Social CRM Use in SME's. Egineering Economics .

Martens, C., Herssens, J., \& Delcourt, C. (2019). Design Supporting a Customer- Percived Intimacy- Strategy In Healthcare Services. Internatinoal Conference on Enginnering Desing, ICED19.

Montecinos, S. C. (2021). New Perspective on Cognetive Dissonance Theory. Sweden: Stockholm University. 
Journal of Business and Strategic Management

ISSN 2520-0402 (Online)

Vol.6, Issue No. 2, pp 63-83, 2021

www.carijournals.org

Murithi, D. M. (2017). European journal of research and reflection in Management science. African small and Medium Enterprises(SMES) contributions, challanges and solution, Vol. 5 No. 1.

Mutuku, G. K. (2018). Strategic use of Information Technology and performance of Machakos Huduma center . Universirty of Nairobi.

Mwaniki, L. N. (2019). Financlial Literacy and Growth of Small Medium Enterprises in Nyeri County, Kenya. Kenyatta University.

Nagwan alqershi, S. s. (2020). Innovative CRM and pefromance of SMEs; The morderating Role of Relationship Capital. Jounaral of open innovation;Technology Market and complexity

Ndhlela, V. s. (2018). Customer Relationship Management as a customer retention Tool: A case study of OK Zimbabwe Limited. . Internatinal Journal of BUsiness \& Management Science. , volume-4, issue -2 .

Njau, F. W. (2019). An intergrated SERVQUAL and Gap Model In Evaluating Customer Satifaction In Budget Hotel in Nairobi CIty County, Kenya. kenyatta University.

Njenga, B. (2018). Effect of selected Factors on The choice of Capital Structure Of Small and Medium Enterprise(SME's) In Kiambu. Egerton Univesity.

Noemi Mendoza-Diaz, B. M. (2020). Face-to-Face and Online Classes in a Technology Management Program: A Comparative Study. Journal of Technology Education, Vol. 32 No. 1.

Noorain Imbug, S. N. (2018). Influence of Customer Experience on Customer Loyalty in Telecommunication Industry. International journal of Academic research in Business \& Social Science. , 103-116.

Nora, L. (August 2019). Testing Customer Knowledge On Customer Intimacy and its impact on Repurchase intention. Journal of Information and Knowledge Management Systems .

Osei, G. (2017). Customer Intimacy Adoption and its Impact on Organization Performace. Journal of Research in Marketing .

Osei, G. ( 2019). Customer Intimacy now Gaining ground in Academia. International Journal of Business and Management Studies, .

Porto, F. A. (2018). Approach of McGregor's and X AND Y Theory Associated with the Adaptive or Non-adaptive culture constuct of Kotter and Heskett: An Emmprical study in Goias,Branzil Approach of McGregor . International Journal for Innovation Educationand Research, 201.

Robert Kwame Dzogbenuku, S. A. (2019). Marketing and Enterpreneurial success in emerging market: the nexus. Innovation and Entrepreneurship .

Robert Mashenene, M. A. (2019). The Influence of cutomer Retention Strategies On customer quality in Higher Education in Dodoma. African Journal of Applied Research .

Ruth N. Bolton, J. R.-K. (2018). Customer experience challenges: Bringing together digiatal, physiacal and social Realms. Journal of service Management . 
Journal of Business and Strategic Management

ISSN 2520-0402 (Online)

Vol.6, Issue No. 2, pp 63-83, 2021

www.carijournals.org

Saheli, L. s. (2018). The impact of CRM stategy on customer Loyalty in SMEs. Internatianal business research, vol 11.

Saheli, L. S. (2018). The impact of of CRM strategy on customer Loyalty in SMES. International Business Research, vol 11, No11.

UNCTAD. (2018). Harnessing Frontier Technologies For Sustainable Development . Switzerland: United Nations. 